\title{
Ibu Sawitri and the a/occidental Oriental
}

\section{Monica Wulff, University of Technology, Sydney}

This paper represents a companion piece or supplement to Dancing in the Contact Zone. In that paper I introduced Ibu Sawitri, her dance, and my experience of our embodied cultural encounter. ${ }^{1}$ The first part of this paper is also devoted to Ibu Sawitri, but is specifically linked to the ideas raised in the Ibu Box camera from the installation. Here I tell 'my' insights and interpretations of Ibu Sawitri's life, which traverses a multitude of colonial and local patriarchies. The story is interwoven with transcripts of Ibu's voice as presented in the installation and a range of other historical Indonesian women's voices drawn from books and archives. In the second part of this paper I look at what it means to leave what Pratt terms the 'contact zone' (1992) with a body that is informed and shaped by this experience. Here I will discuss some of the main issues addressed in my camera box and the wall projection. I look at western audience reactions to the contemporary work I do in Australia with the dance and performance techniques learned in Indonesia. Based on these reactions I speculate about western perceptions of traditional and modern Asian art forms and what that says about our current western perceptions of Asia.

\footnotetext{
${ }^{1}$ For more background information about the installation, which represents a cross-cultural collaboration between Sydney based director Deborah Pollard, video artist Sam James, sound artists Gail Priest and myself as concept devisor and performer, as well as Indonesian based sculptor Hedi Heriyanto, and explanation of the term 'contact zone', please refer to my other paper in this special issue of PORTAL.
}

PORTAL Journal of Multidisciplinary International Studies vol. 3, no. 2 July 2006

ISSN: $1449-2490$

http://epress.lib.uts.edu.au/ojs/index.php/portal 


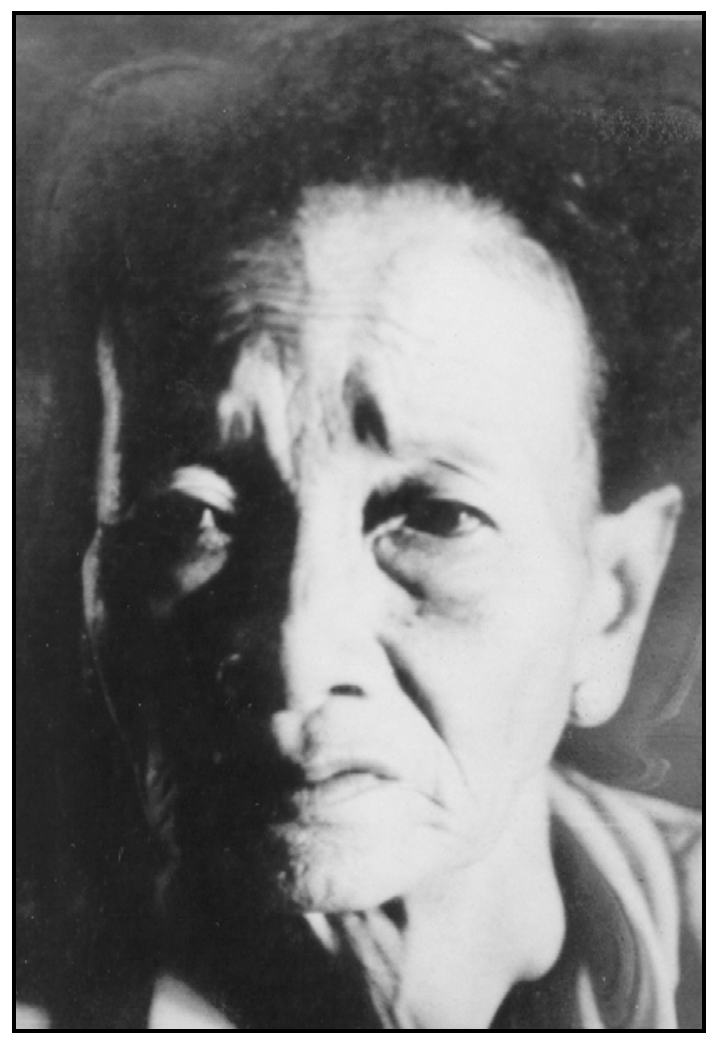

Bapak Sumitra, Ibu Sawitri's father (Family photograph, date unknown)

\section{Ibu Sawitri’s dance with history}

The thing that impressed me most about Ibu's life was that it spanned a period of incredible political upheaval and social change. My name is Sawitri. I am 75 years old. I live in Astanalanggar, Losari, in Indonesia. She was born some time around the mid1920s in Losari, Cirebon under Dutch colonial rule. When I asked her what she remembered about that period she told me that she did not remember having had contact with Dutch people in the village or the local surrounds, but occasionally she saw them at a distance closer to town. It was still the era of Queen Wilhelmina, I was a little girl then. The Dutch ruled through a regional bureaucracy, which reached the villages via the tentacles of government in the form of Gubenur, Bupati, Lurah, RW (Rukun Warga) and RT (Rukun Tetangga). ${ }^{2}$ This local government/villager relationship was based on fragile trust and exploitation, the parameters within which Ibu learned, in the course of her life, to negotiate with considerable skill. The Dutch featured in Ibu's

\footnotetext{
${ }^{2}$ Governor, regent, village chief, administrative unit at the next-to-lowest level in a city consisting of several RTs, and the neighborhood association, the lowest administrative unit (Echols \& Shadily 1992).
} 
life through their absence, but affected her life directly through the system of top-down rule, which at times involved forced labour in government-owned rice fields and local industries. As Pak Wastar, one of the oldest gamelan Topeng Losari musicians remembers, as verified by Sulastiyano: ““Tahun 1930-an merupakan masa sulit pangan, karena sawah-sawah tidak ditanami padi melainkan tebu.” Kenyataan ini disebabkan karena pemerintah Hindia Belanda menjadikan Cirebon sebagai pengekspor gula terbesar' (cited in Masunah 2000, 47) [“"The 1930s were a time of scarcity because the rice fields were not planted with rice but with sugarcane.” This situation was the result of the Dutch East Indies Government making Cirebon its largest sugar exporter']. This historical condition is confirmed by Soekesi: 'Daerah pesisir utara banyak terjadi penyewaan desa-desa atau daerah kepada orang partikulir yang kebanyakan orang Tionghoa (Cina). Mereka berkuasa atas tanah beserta penduduknya terutama dalam menentukan pajak dan wajib kerja bagi penduduk guna keperluan pabrik atau perusahaan gula mereka' (cited in Masunah 2000, 48). ['In the north coast region there was much renting out of villages and regions to individuals, many of whom were Chinese. They were in charge of the land and its occupants in particular in the role of demanding land tax and forced labour from the residents to satisfy the demands of their factories and sugar companies’].

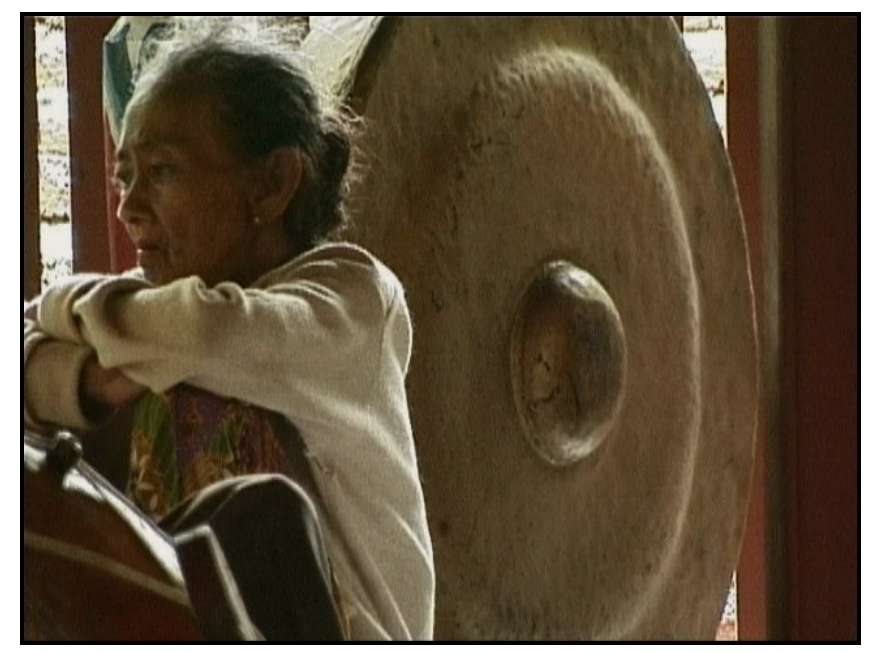

Ibu Sawitri sitting amongst the gamelan, Losari/Cirebon 1999

Close government control through the local bureaucracy was a constant throughout 
Ibu's life, given that the Dutch system of law and government was maintained in independent Indonesia. Ms Kurnianingrat, known to her friends as Jo, an educated, Indonesian woman from a noble background who did have direct contact with the Dutch, tells how she experienced Dutch rule:

So far my life had been so protected that I did not notice the injustices around me. I did not know there were certain swimming pools with the notice: Dogs and natives not allowed entrance. I had no idea that it was difficult for Indonesians to be accepted at the European Primary School, which paved the way for future good schooling. I did not realise that for most Indonesian children it was made difficult to get a good education and I was oblivious of the fact that the masses were kept ignorant and poor (Thompson Zainu'ddin 1997, 169).

The Japanese occupation (1942-1945) and the hardships experienced during this time were vividly and frequently recalled during our conversations. From Ibu’s stories it emerged that the Japanese were present in the village and deeply resented. When the Japanese landed here, I could already dance. All the bridges were bombed, so if you wanted to cross the river you had to go by raft. Ibu told of how she and other women would rub their faces, arms and necks with mud before venturing out into the village. If they saw Japanese in the distance they would turn around and insert their round enamel bowls called baskom used to carry rice and other goods from the markets under their sarongs to give the appearance of pregnancy. The dirty appearance and pregnant bodies were supposed to repel the Japanese soldiers and guard the women against rape. That was my experience when I was young. I wasn't afraid of anything. When the Japanese were walking in the streets, they never let you pass, wherever they were, they would hit people with wooden sticks. So, that's my experience, I don't understand anything about politics, I just know what I saw. One day when we were coming back from the market Ibu greeted a neighbour and then proceeded to tell me that particular woman's mother had gone insane during the Japanese occupation because of having been taken away by Japanese soldiers, presumably to serve them sexually as a comfort woman. Since that day she had been unable to participate in society and would cower, shake and scream if planes flew overhead or during a thunderstorm. She was terrified that the Japanese were coming back to bomb the village. Her story might have been the same as Momoye’s, the name another Javanese comfort woman was given by the Japanese. She remembers her ordeal in an interview with Jawa Pos on April 29, 1993. 
At the start I didn't know I would become an ianfu. I was still living in a kampung in Yogya with my parents and three brothers and sisters, who've all died. In order to lighten my parents' burden, I decided to look for work. I heard from friends that there was a Japanese Dr. Sunginga offering jobs to people. I went and registered hoping I would get work in a restaurant or as an actor on the stage in Kalimantan. After getting agreement from my parents, finally I left by train for Surabaya. At the station I found lots of others who had the same destination as I did. From Yogya 40 women left for Kalimantan, but most were older women (sudah dewasa). There were only four of us 13 years or under, including me. In Surabaya we were given two sets of clothes and Rp. 8 pocket money and went by boat to Banjarmasin. Now, it wasn't until we got to Banjarmasin that we found out what our real work was, when we got put in a hostel with a three meter high fence around it in the Telewan district near Rambai market. I was allotted room number 11 . A Japanese gave me a health check up. And that was when, for the first time, I was forced to serve the lust (melayani nafsu) of the health worker. After that I just suffered more. Especially as I had to serve up to twenty Japanese per day. Just imagine, I had to work from $12.00 \mathrm{pm}$ until the next morning. From 12.00pm until 5.00pm we were raped (dipaksa melayani) by Japanese soldiers, then from $5.00 \mathrm{pm}$ until morning by Japanese civilians. So you could say that we were raped once an hour by the Japanese who lusted like devils (nafsu setan). So we could only rest in the morning. Not to mention the punishment we got for mistakes, such as keeping a customer waiting.

After I was five months pregnant, I was forced to have an abortion. I was in a state of real shock over this, especially as they made me see my unborn child after the curette. I fainted, and I will never ever forget their treatment of me (cited in Lucas 1997, 75).

According to Hicks, the method of recruiting comfort women for the Japanese military brothels ran parallel to the recruitment of the forced labour system, namely via the local and village officials (cited in Lucas 1997, 74). Ibu escaped Momoye’s fate as an ianfu but was subjected to forced labour like everybody else in the village. People were forced to work and were paid with beatings rather than food, that was the Japanese era. The Japanese era was very hard. Lots of people went missing, they were taken to Jatiwangi and never came home. I don't know what became of them. Because of a longlasting drought at the time and farmers being forced to grow cash crops for the Japanese, they were unable to grow rice. Widespread famine was the result. High inflation during the occupation, the inability to import yarn and hoarding of cloth by the Japanese in aid of the war effort, meant that clothing and cloth were almost impossible to obtain. Even the black market in cloth was forced into non-existence due to the scarcity of cloth. Ibu would scrunch up her face in disgust when talking about being forced to eat low quality rice mixed with corn and gravel that tasted bad and was also very scarce. She remembered being constantly itchy from lice infestations caused by rat plagues, lack of soap, and wearing hessian sacks. She even succumbed to buying a rubber sarong (sold as a cloth substitute at the time) and told me with great amusement that it completely 
warped out of shape after she washed it and hung it in the sun. In the following quote, a nameless voice on the hardships experienced by women during the occupation echoes from deep within the Indonesian National Archives:

As a woman I was very moved (sangat trenyuh) to see the situation of women (in the Tanjung Priok area of Jakarta) who were forced to wear rubber sarongs to cover their bodies. If they were menstruating and had to walk somewhere, the blood trickled down their ankles, because they had no (menstrual) cloths. This was terribly sad (benarbenar sangat menyedihkan) (cited in Lucas 1997, 71).

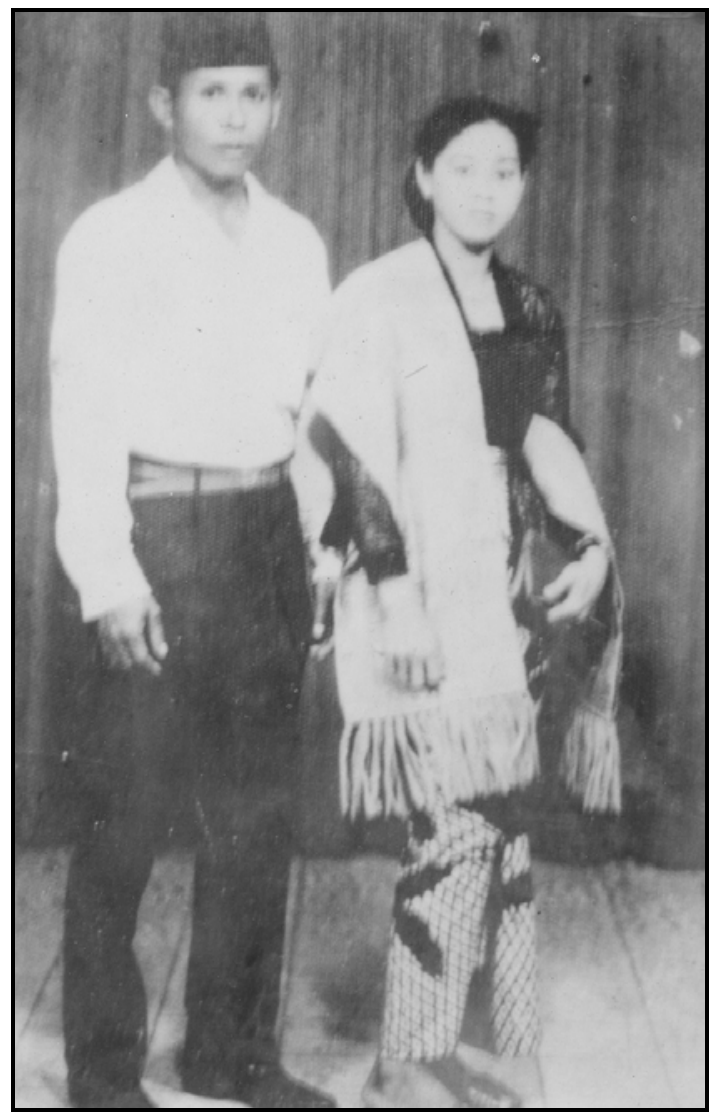

Ibu Sawitri in her late thirties with Pak Pade, husband number six (family photograph, date unknown)

Jo Kurnianingrat, who became a senior member of the Ministry for Education under President Soekarno, made this observation about the Japanese occupation in her memoirs:

Three and a half years is a relatively short time but it was a devastating period. I am not thinking of the cruelty of the cash troops because cash troops, no matter what nationality, seem to be cruel everywhere, but their Kempeitai, a kind of Japanese Politbureau, was notorious for its cruelty. The wealth of Indonesia was scooped up and used for Japanese war purposes, leaving the people poor and hungry. The Dutch and Indo-European men and women were put in separate camps and often 
the men were transported to other countries to do forced labour. This happened to a lot of Indonesians too. When they did come home they were emaciated and not capable of much (cited in Thompson Zainu'ddin 1997, 71).

Ibu was married for the first time at the age of ten in a misan match arranged by her father with the aim of fortifying a particular family tie. ${ }^{3}$ When I was 10 years old, I was married off by my father. I had no idea. I ended up asking to divorce my first child husband. Since this marriage was not consummated Ibu was left a janda kembang (a virgin widow) after her divorce. One year later somebody proposed to me. His name was Sahari and my father accepted. I was 14 at the time. Now a teenager she entered her second arranged marriage, this time to Sahari, the son of her pencak silat (Indonesian marshal arts) teacher. I became pregnant and had a child. He was a local village clerk. By the age of fifteen Ibu was pregnant. In her seventh month of pregnancy she became very ill with a tumour on her neck and gave birth at nine months to a baby girl named Mulyani while she was still sick. My child was getting bigger, but then at the age of two, she died of smallpox. After the death of her child when Sawitri was seventeen, she and Sahari divorced, after which she met and married Sugimin, a policeman from Purworejo. These were the years of the Indonesian fight for independence, which Ibu remembers with a sense of pride combined with sadness at the human toll and the loss of her own daughter. During that time our Independence fighters were able to defeat the enemy. In those days we weren't called a republic yet. Jakarta wasn't called Jakarta, it was still called Batavia. She often talked fondly of Soekarno and his charismatic leadership qualities.

Since the age of nine Ibu had been actively dancing and was also well on the way to becoming an accomplished dalang wayang kulit (wayang shadow-puppet narrator and puppeteer). I married a policeman after that, but we were only married for six months because he wouldn't let me dance. She was in popular demand at the time she married Sugimin and had a busy schedule of performances during the festive months. Before Ibu married Sugimin she explained to him that she was a descendant of a long line of

\footnotetext{
${ }^{3}$ By misan is meant a match that involves the marriage between the children of siblings. The symbolic aim of these marriages is to strengthen family ties and they are not expected to be consummated (Sawitri 1996).
} 
mask dancers and dalang wayang kulit, that it was her calling and that she would not give it up for marriage. She asked him if he still wanted to marry her. He said he did and she made him sign a letter agreeing to this, which she had drafted through the village officials. After they were married for a while and Sugimin being of a jealous nature, he started to follow her to performances that lasted from sunset to sunrise in order to keep an eye on her. Sawitri took great offence at this and on one occasion when he followed her to Gebang, a neighbouring village, she angrily sent him back home. The next morning when she had finished the wayang play, she went home via the Kantor Urusan Agama (KUA; the Office of Religious Affairs) and divorced him there and then. She felt angry and offended that he had not kept his promise to respect her vocation. I would rather not have a husband than not dance, full stop! Ibu, I am told by other older villagers, was a beautiful young woman with an independent career that was paying her way. ${ }^{4}$ She didn't need to put up with Sugimin's jealous and often abusive behaviour. Sugimin was apparently horrified at her decision and tried to talk her out of it, but she would not hear of it. Village women with independent means of income can operate with a certain amount of freedom within their private realms compared to middle-class women who are tied to stifling middle-class codes of morality and the expected status of loyal and obedient housewife. ${ }^{5}$ These women tend to avoid divorce because many are economically dependent on their husbands and fear the shame brought about by divorce. ${ }^{6}$ Kartini writes about her period of forced seclusion before marriage, which despite being written over 100 years ago, still aptly describes the frustration and pain of this kind of dependency:

\footnotetext{
${ }^{4}$ Divorce and remarriage were and still are relatively common in Javanese villages and are not as socially frowned upon as in the middle class. Ibu Wiri, Ibu Sawitri's cousin, also a dalang wayang was married and divorced nine times.

${ }^{5}$ Under the Indonesian New Order Government of President Soeharto 'woman' was equated with the status of mother and housewife destined by nature. Soeharto talks about his views on Indonesian women in reference to their role in national development in his autobiography: My Thoughts, Words and Deeds: Autobiography as told to G. Dwipayana and Kamadhan K.H, in the chapter titled Concerning our Women: 'to bring Indonesian women to their correct position and role, that is as the mother in a household [ibu rumah tangga] and simultaneously as a motor of development...We must not forget their essential nature [kodrat] as beings who must provide for the continuation of a life that is healthy, good and pleasurable'(Soeharto cited in Tiwon 1996, 59, her addition of Indonesian words in brackets).

${ }^{6}$ This trend is changing among educated upper- and middle-class women in large cosmopolitan cities like Jakarta and Bandung, where divorce is on the increase.
} 
My prison is a large house, encircled by spacious grounds. But it is encircled by a high stone wall and this kept me imprisoned. No matter how large the house and garden, if you are forced to live there you feel stifled. I remember how, in silent desperation I flung myself at the eternally closed door against the cold stone walls or a locked door (Kartini cited in and translated from Dutch by Tiwon 1996, 51).

Ibu was eighteen when she divorced Sugimin. She was still suffering from the loss of her child and there were rivalries among other dalang wayang family members who were jealous of Ibu's success. The spread of a more conservative Islam that was increasingly critical of elements of animism within older traditional forms of Islam was dramatically shrinking the demand for Topeng. These factors prompted Ibu to join her aunt who was working in Palembang in South Sumatra. After my child's death I was very unhappy and so my aunt took me to Palembang with her. She did however regularly return to dance during the festive months, which still provided some work. ${ }^{7}$ In Palembang she met and married her fourth husband, Darmansyah, a Muslim religious teacher from Banjarmasin. She lived with him in Banjarmasin on the island of Kalimantan for three years. During the fourth year of marriage she divorced him and returned to the village to become part of the dance troupe again.

Some time after this, while she was back working with her aunt selling fruit and vegetables at the market in Palembang to help support her family back home, she met and married her fifth husband. It's there that I met the pilot. I married him, but it turned out he was already married but had told me he wasn't. I found out from a friend of his. I don't like being lied to, so I left him and came back to Java. She never mentioned his name and mostly just referred to him as si pilot kapal terbang (the Pilot). Ibu was angry at being taken for a fool and went back to Java without a word. Si Pilot followed a while later and she told him she refused to be a second wife to a liar. He pleaded and wouldn't leave without her. In the end she told him to go home first and that she would follow in a few weeks when her dancing schedule was over. He did and she proceeded to send him the divorce papers. Ibu met and married her sixth husband, Pade from

\footnotetext{
${ }^{7}$ Poorer fishing villages less influenced by the more conservative city Islam still regularly hire Topeng Losari performances for ritual occasions during the festive months. Up until the 1965 communist coup many Chinese families regularly hired Topeng Losari in various capacities for Chinese New Year celebrations and weddings. This practice stopped altogether after the coup (Masunah 2000).
} 
Makasar, in Palembang. He was ten years her junior and somewhat of a geek. Ibu used to talk about being embarrassed to walk with him because he always had his shirt half hanging out of his trousers or a shoelace undone. Eventually I went back to Palembang. There I met my last husband. He was the least handsome, most stupid and obliging of all my husbands. We were married for sixteen years. She said however that he was a good and patient man who adored her and had a steady income as a rice distribution clerk. They managed to buy three houses from their joint efforts.

During her marriage to Pade, and not long after her father's death, Ibu witnessed the 1965 communist coup in Palembang. She talked about seeing rivers turned red from blood. I was in Palembang. Every day at least ten corpses were thrown into the river. She saw frightened people being rounded up and led into prison compounds with high fences close to the market she worked at. She returned to Java shortly after the event to check that her family were safe. Here in Losari it rarely happened. It's just that people went missing. I don't know where they went. Whether they were killed or not, I don't know, but until now they haven't come home. Artists and dancers had reputations of belonging to the socialist artist organisation LEKRA, so during this time and for years after, Ibu’s family did not perform for fear of being labelled communists. Village officials would pick on you if you weren't carrying the right kind of papers. They would say: 'You are a communist and if you don't want to be detained you have to pay me'. That's how cruel the village officials were, they blackmailed their own people. We didn't perform for a long time after that. Artists were accused of being communists. Her relative prosperity in Palembang was now more needed than ever.

Prior to the communist coup, Ibu was recalled to Java to tend her dying father who on his deathbed entrusted the dance and its future survival to her. She returned to Palembang after he passed away, but in the years that followed became increasingly concerned about keeping her promise to her father. Ibu took this calling very seriously and eventually decided to leave her husband and return to Java to teach the next generation how to dance. Given the fact that Ibu had never been able to conceive again after the birth of her first child, she was able to wean herself from her relationship to 
Pade by convincing him to marry her household helper to ensure that he could have children. He was unwilling at first but finally consented under the condition that Ibu would not remarry. She kept her promise and from that day forward said she was married to her dance and would do all in her power to pass it on to the next generation.

In the mid 1970s the government and Jakartan patrons of the arts were showing a resurgent interest in traditional arts regarded as on the verge of 'extinction,' due to the traumatic effects of the communist coup and growing Islamic conservatism. Traditional arts were no longer seen as potentially subversive, and were absorbed into the New Order propaganda machine to passively reflect the happy image of a unified, harmonious Indonesia. This is when Ibu and the new generation of dancers and musicians began to be invited to perform outside the village at government-sponsored events. It would appear that Soeharto’s New Order was employing the same strategies of divide and rule, or better still diffuse and rule, that its Dutch predecessors had perfected during the era of the Dutch East Indies. It is a history that also fits into Ghassan Hage's idea of 'political necrophilia'. Once the threat of those perceived as subversive had been eliminated, the Soeharto Government could show concern and assign money and resources to keep the appearance of those art forms alive.

Under the Soeharto Government, and with a growing interest from artistic circles in the bigger cities, Ibu managed to make a living from her dance. During hard times she supplemented her income doing odd jobs. Ibu's long experience of surviving hard times, and the additional income from the new performance context created by the Soeharto Government, allowed Ibu to maintain her dance, if in a new and changed form. She was forever haggling with government officials who were helping themselves to hefty commissions whenever she performed for the government or received government grants to build or repair her studio. By the time she received payment it was often only half of what she had signed for. Privately she would get very cross about this, but when confronting officials she knew there was only so far she could go without losing their support altogether. Soeharto kept on developing and building buildings, but how come he got to be so rich? He sucked his own people dry, so that in the end the ones with 
nothing expected nothing and the ones living it up lived it up even more. I will never forget the banter and self-assured, patronising laughter of the government officials dressed in tight khaki pants, heavy black boots and greasy slicked back hair, at Ibu's deferential, playful but heartfelt attempts to get the officials to pay her fairly. In the last years of her life Ibu witnessed the downfall of the oppressive Soeharto regime. Stories of the New Order's rampant corruption and nepotism were for the first time being openly verified and discussed on television. Now the people understand what happened, we can't be lied to anymore.

Ibu reached the limit of her patience at the growing conservatism and narrowmindedness of Islam in the village when she overheard a sixteen-year-old religious preacher declare, over the local mosque loudspeaker, that public dancing and singing was haram. I used to listen to religious sermons from the loud speaker of the local mosque everyday. One day, a sixteen-year-old Kiyai, told in his sermon that to go on the Haj to Mecca with money earned from dancing or singing was haram and unclean. I was very offended by this. This statement was clearly unacceptable and insulting to Ibu and becomes even more so in light of the fact that Islamic influences are an integral component of Topeng Losari. The traditional performing arts played an important role in the spread of Islam in Java. As a result many of these traditional art forms are intrinsically connected to Islamic religious belief. The Wali Sanga, the nine disciples, who are believed to have first introduced Islam to Java, are prayed to at the beginning of every performance. Their spirits are believed to reside in the various gamelan instruments and their function during performance is to guard the four-corners of the performance space and to bestow blessings and safety on those participating in the ritual occasion. That afternoon I marched off and confronted the preacher. I asked him whether he burned incense before he went off to preach anywhere. He agreed. I told him that I did the same. I pray and offer incense before I dance, just as he does, how could that be haram? If he can accept money from his efforts and go on a Haj, why can't I? He was a hypocrite. I don't believe him. I am sure that God accepts me and my dance. That Kyai was corrupt, he's dead now. Leaders of mask troupes, like Ibu's father Sumitra, were considered to be charismatic leaders and holders of important 
ritual and spiritual knowledge. They were consulted much like the village dukun (spiritual healer and seer) for guidance in emotional and spiritual matters. The knowledge these leaders drew on was documented in large religious books called primbon, which contain traditional pre-Islamic and Islamic-influenced spiritual teachings and knowledge.

In her lifetime Ibu would have liked to go to Mecca, but was never in a position to afford the journey. In my life I have never had to be dependant on anybody else. Any money she made from dancing went towards repairing the studio and maintaining the dance troupe. Weekly rehearsals on Sunday involved providing lunch, snacks and cigarettes for all gamelan players and dancers. Costumes were in constant need of maintenance and new masks were ordered to supplement the old ones as well as the repair and repainting of the very old masks. Ibu was good at saving and making grow whatever money she did earn. Nobody has ever had to take pity on me by giving me food to eat. By Allah, never! Even if my life is full of bitterness and shortcomings, no matter what, I can take it, I can survive! Sadly, even with the support of students and patrons, much of the money she earned in the last few years of her life, by which time she was becoming famous as an old master and frequently asked to perform, was used for medical purposes, which Ibu resisted whenever possible. Whatever my fate, I will never give up trying. God is the one who planted my seed, he is also the one who will come and take me away. In death all people are the same.

Ibu's Sawitri's dance gave her a sense of self and purpose in life. These two factors provided Ibu with an agency that allowed her to dance across the boundaries of the numerous patriarchal power constructs that at times threatened to topple her. Perhaps Ibu's voice doesn't carry far enough to make it heard in a context that 'counts'. It was nevertheless a voice that spoke loud and clear to me. Her commitment to and belief in her dance and its future, together with her determination and strength of character, drew me to her, hence my hope that it reaches a wider audience in this re-citation. Ibu Sawitri in life and beyond continues to inspire my own determination to survive as an artist in a world dominated by a conservative corporate patriarchal power construct, within which 
the arts and humanity alike are battling against an ever-shrinking global platform to practice on and be heard. I would like to finish this section with this last memory of Ibu.

One of the last and saddest conversations we had was during the end of my 1999 stay in the village, Ibu insisted on coming back home to the village from the hospital she had been admitted to the week before. It was late at night, she had been coughing incessantly and was visibly in pain. After the painkillers had started to take effect and I was massaging her back, she quietly started talking about the time she gave birth to her baby daughter at the age of sixteen when she herself was delirious with fever from a tumour on the side of her face and neck. She spoke in a quiet voice about the son of an important revolutionary fighter who was known to have healing powers who had been called on to help cure Ibu's tumour. Through various methods, the details of which I no longer recall, she was eventually healed. She can't remember her own child's birth, only that she and the baby were well when she heard the news months later that the young man who had healed her had not returned from the independence fight against the Dutch. The only thing that was returned to his family was a neatly folded pile of his clothes. Her own husband returned from the guerrilla fight alive. She stopped talking then. I left Ibu's room feeling helpless and sad in the face of her illness that was mercilessly draining away a formidable life force. With the imprint of her bony, frail body still alive in my hands and deeply affected by her quiet reminiscences, I walked outside for a breath of cool night air. Mang Tara, Ibu's nephew, a father of three, was sitting outside Ibu's window. He looked sad and concerned and told me that he had never heard Ibu telling that story before. The very last thing Ibu ever told me when I called her from Australia shortly before her death was: 'Dunia ini tidak selebar daun kelor,' the world is bigger than a kelor leaf.

\section{Taking the dance home: theft, appropriation hybridity or fusion}

What happens when you embody a form of dance learned in its home context and then walk away with it? What happens furthermore when you use this dance as a language in a new and different context? You are not new to the context, but the dance you are 
carrying with you is. Early in my dance career, a contemporary performer referred to my work as being 'colonial'. The comment was made in response to the question about what the difference was with somebody like myself who was creating work derived from traditional Indonesian dance forms and somebody working with other Asian forms like Butoh or the Tadashi Suzuki actor training method. This comment triggered the investigation that informs Troppo Obscura and this paper. By way of introducing the cacophony of angst-ridden questions which this comment provoked and which I now intend to address more directly, I will quote them here.

Is the performance work I am doing good or bad appropriation? Is the way I use Indonesian dance and training technique in a contemporary context in Australia ethical or even legitimate? Am I perpetuating the role of the colonizer by 'taking' the dance for my own expression without giving anything in return, reminiscent of the historical colonial plunder and disregard for traditional context and meaning? Am I adorning myself with 'other' exotica to make up for the fact that I have 'no' culture? Am I using Asian dance as a 'spicy sauce to make some old familiar gruel palpable again' (Weber 1991, 30)? Do I wear an Asian mask to hide my 'whiteness,' which implicates me with historical guilt?

In the next section, I discuss the camera box inside which I perform and the wall projection in reference to my artistic and personal relationship with Ibu Sawitri and the theories and ideas raised throughout this chapter.

\section{Stomping and butoh versus Topeng Losari}

From the early 1990s onwards there was a growing trend among Australian performers to travel to Japan and undertake beginners’ workshops in the Suzuki method at the SCOT (Suzuki Company of Toga) home in a remote mountain village in Northern Japan. $^{8}$ Many returned to take master workshops that qualified them to teach the form once back in Australia. In the relatively close-knit performance scene it was almost imperative to undertake training in the form if you were to be taken seriously as a performer. In 1996, not wanting to be left out, I was a student of the Suzuki method, taught by Meme Thorn during a six-month intensive actor training project with Sidetrack Performance Group.

\footnotetext{
${ }^{8}$ In the Sydney performance scene the Suzuki method was usually referred to as stomping because many of the movements involve stomping the feet on the ground with full force with a counter-restraining move just before impacting the floor.
} 
Based on my experience of learning Suzuki and from papers written about the method, I started to make mental comparisons between the Suzuki method and those I had developed based on training in Indonesian dance. The motivation behind this was to try to understand why the two Japanese forms were viewed so differently from my Indonesian-based style by the Australian performance audience. It was my suspicion that the difference in perception between these two forms had more to do with the way that Asia is constructed in the mind of the Westerner, rather than any real reflection on the differences of these forms.

Both the Butoh and the Suzuki method draw on influences from much older forms such as Noh and Kabuki. In both these modern adaptations there is an emphasis on the body being grounded with a strong central focus, unlike traditional and modern Western forms, which are more concerned with a movement upwards and across large areas of space. As was written in a SCOT Festival Publication:

\begin{abstract}
At the core of the Suzuki Method training is an emphasis on the movement of the lower body and feet, with special attention paid to the pelvic region (the actor's centre of gravity), which are also the areas of emphasis for the actors training in the traditional theatre. In contrast to the heavenward orientation inherent in the erect posture encouraged by Western theatrical training, this technique directs the energy of the body downward, earthward; the natural movement that results is derived from body movements employed in traditional farming in Japan (Senda in Cohen 1996, 53).
\end{abstract}

Suzuki talks about modernization having 'dismembered our physical faculties from our essential selves' and that is what he is striving for with his movement training: to 'restore the wholeness of the human body in the theatrical context.' He aims through his form to make available to his students the 'discovery of an inner physical sensibility’ and an 'inner and profound memory innate to the human body’ (Suzuki 1991, 243).

These principles also apply to most forms of Indonesian traditional dance. The forms I studied certainly conform to this principle. The abdomen and pelvic region are where the energy of the dance is harnessed. This is necessary because the legs are often bent low and the body weight is shifted across the central axis to accommodate movements 
that often go against the natural centre of gravity. Another function of the still, grounded centre is to operate as a contrast to the dynamism of the extremities such as hand, feet and head movements. A mental image and body sensation developed from my experience of learning dance in Indonesia is of the centre as source of energy, which is channelled along threads connecting all parts of the body. The sensation is of a tangible feeling of energy emanating from the centre to the more peripheral parts of body that are employed for expression. Body memory is another example of a deep, inner-body awareness that is developed by hours of watching, practicing and internalising dance movements.

What I have tried to demonstrate here is that Topeng Losari mask dance and the other forms of Indonesian dance I have learned over the years have become my movement vocabulary and performance training technique. It is my first language, if one is to speak of dance as a language. Prior to learning Indonesian dance I had no formal dance training. This dance training, which I began in 1983, is an ongoing, ever-evolving process. The performance skills I have learned over the years inform my work in a multitude of ways. At times this influence is very direct, for instance when I draw on movement vocabularies, at others indirect, as when I am using embodied performance techniques or images of dance to support whatever it is I am trying to express on stage or within an artwork. Stylistically my dance training is different and yet it draws on similar fundamental performance techniques contained within both Butoh and Suzuki. Although Topeng Losari is a traditional form that has not been theorized and processed into a modern movement philosophy in the same way as the Suzuki method, I would argue that Topeng Losari as a movement and performance discipline is equally effective.

\section{Boxing the colonial}

The question, then, of why my work was perceived as 'colonial' still remains to be addressed. I believe it has something to do with the fact that Indonesian traditional dance is seen as a 'classical,' fixed Asian form that comes from an ancient tradition which should not be interfered with or appropriated in the way that it is seen to be in 
my performances. There seems no equivalent concern with the use of Butoh and Suzuki. Is it because Butoh and Suzuki have originated in a modern context within an economically affluent 'first world' Asian country such as Japan? In contrast, is Topeng Losari not acceptable as a performance discipline because it is an unprocessed, traditional form, from an economically disadvantaged, politically challenged 'third world' country? As I have already argued, Suzuki and Butoh both draw on older, traditional sources and when these forms are analysed in juxtaposition with the Indonesian dance training in terms of their usefulness as a performance discipline, they exhibit comparable benefits. How is a form like Butoh that was developed in reaction to the very specific experience of the post World War Two nuclear holocaust in Japan, more relevant to an Australian performer than a traditional Indonesian dance form?

The notion that traditional Asian art forms are somehow pure, sacred, untouchable and eternally unchanging, says less about the actual evolution of these art forms and more about a romanticized notion of them. These notions are created in the West and then imposed onto Eastern forms. This inability to accept the possibility of change and transformation of a people and their cultural expressions is a way of silencing and boxing the Other. The perception in the West seems to be that 'ancient,' 'exotic' and 'oriental' objects and cultural expressions must be kept untouched and unchanged so that they can shimmer and radiate the mysterious promise of another world, so unavailable in the West and so closely connected to notions of beauty, desire and a lost past. It would appear that there is no other space for these cultural forms than the museum, and the glass display cabinets for these traditional art forms, where they are categorised, fixed, known and as a result killed off. The form and practitioners of the Topeng Losari mask dance had to change and reinvent themselves continually in order for the dance to continue existing as it has done for centuries. Said refers to the paralysing effects of what I call the 'western glass cabinet gaze': 'Moreover the male conception of the world, in its effect upon the practicing Orientalist, tends to be static, frozen, fixed eternally. The very possibility of development, transformation, human movement - in the deepest sense of the word - is denied the Orient and the Oriental' (1996, 35). This notion of the Orient as a 'known,' mystical, spiritual and exotic entity 
is at the core of the continual emergence of Asian-based new-age religions and shops selling all things Asian. This perception of the exotic Asian Other appears to have more to do with what Westerners experience as missing in society rather than any real understanding of that which is Asian. In an attempt to find meaning, it is the repressed desires and yearnings of the person searching that dictates what is being perceived as the 'answer' to the quest for meaning. Torgovnick cites Lukacs to describe this Western condition:

In his history of the novel, Lukacs sees the condition of the modern Western mind, the mind that produced the novel, as 'transcendentally homeless': secular but yearning for the sacred, ironic but yearning for the absolute, individualistic but yearning for the wholeness of community, asking questions but receiving no answers, fragmented but yearning for immanent totality $(1991,188)$.

Perhaps the reason my reinterpretation or use of traditional Indonesian dance within a contemporary performance context in Australia is not always readily accepted is because it somehow touches on this deep-seated Orientalist perception and is thus seen as 'bastardising' or even 'destroying' a traditional Asian form. A form that by way of being traditional and Asian falls into the category of Other, evocative of the mystical Eastern wisdoms contained within its very form, which if not preserved in its original state could be lost forever. Schechner warns about the dangers inherent in the drive to save 'threatened cultures,' with an argument that recalls Hage's notion of 'political necrophilia':

These attitudes barely conceal a kind of primitivism whereby threatened cultures (the Tagalogs of the Philippines, for example) are perceived as 'living museums' of the way humans 'used to be'. Also interventions based on 'saving' or 'protecting' cultures, although high sounding, often are late twentieth-century versions of the racist patronization or imperialist ambitions that glossed and glosses the work of missionaries whose avowed purpose was, and is, to 'save' and 'civilize' people who were and are thought to be savages/heathens (ripe for exploitation) $(1991,309)$.

So far this discussion has centred on audience perceptions of my work in the West. What is more important, in my opinion, is what my teacher Ibu Sawitri thought about the contemporary work I do, informed in part by her dance tradition. I had been creating performances using elements of Topeng Losari for years before I summoned the courage to show Ibu photos of the work I did and to ask her how she felt about it. During a long visit in 1999, when Ibu had been in and out of hospital and I knew it was possibly going to be the last time I had to spend with her, I asked her. Ibu referred to 
the work I was doing as Kreasi Baru (new creations), the term used at Indonesian dance schools for contemporary dance work based on traditional dance. ${ }^{9}$ She had no objections to me using her dance in this way, as long as I made it clear that it was 'inspired' by Topeng Losari, but was 'not' Topeng Losari itself. If I was to perform the dances true to how I had learned them, wearing traditional costume and mask, accompanied by the appropriate gamelan music, then I was to call it Topeng Losari and nothing else (Sawitri 1999). I was relieved at her response and glad that the work I had created in the past had never violated these conditions.

Regarding the debate outlined in the title of this section; theft, appropriation, hybridity or fusion, Daryl Chin asks an important question about this issue: 'The idea of interculturalism as simply a way of joining disparate cultural artefacts together has a hidden agenda of imperialism. When is interculturalism a valid expression of the postmodern crisis in information overload, and when is it merely a fashion statement of the ability to buy and sell anything from any culture?' (1991, 87). Artists, like other professionals, need to make a living in capitalist, commodity-based societies. One way of doing this is to follow the current 'themes' being promoted by the various funding bodies. If multiculturalism, in particular Asian/Australian collaborations, are being promoted by these bodies, the result is a proliferation of work based on these issues, created by artists in order to make a living. Some of the projects funded will be genuine, in-depth explorations on the subject and others will be the 'Chop Suey' variety (Weber 1991, 30). The market place for these intercultural works is domestic and international cultural festivals. Weber draws a distinction between two types of intercultural work found at the festival market place. One, he refers to as 'transculturation, ${ }^{10}$ and the other, 'acculturation'. He defines these terms as follows: 'Transculturation could indeed be defined as the deconstruction of a text/code and its wrenching displacement to a "historically and socially different situation”.

\footnotetext{
${ }^{9}$ Ibu knew this term because her niece Nani, one of the troupe's most talented dancers, had been sponsored by Jakartan and Bandung arts patrons to study at ASTI, the main academy for performing arts in Bandung. Part of her dance curriculum included contemporary Indonesian dance that draws on traditional dance forms for its inspiration. This modern dance is called Tari Kreasi Baru. I often witnessed Nani performing her new choreographies when she was at home in the village during university vacations. These performances were greatly enjoyed by the family, including Ibu.

${ }^{10}$ For a detailed genealogy of transculturation see Pratt (2000) and Allatson (2002).
} 
Acculturation, then, would be the inscription of a preserved foreign code in a native structure, which implies that an ideology is inscribed with it’ $(1991,35)$.

Transculturation, as Weber defines it, is a transformation and re-codification process to make the borrowed text or technique gain its own identity of form and of content, within a new socio - historical context. Acculturation, on the other hand, is a form that is borrowed with relatively minor changes, if any, within a new context. Acculturation in avant-garde theatre was often the precursor to a form that would later develop into a transcultural model. Applying Weber's terms to my own work I am suggesting that mine is a form of transculturation, as I hope has become clear from the process of discussion of Troppo Obscura in this paper. Audiences, on the other hand, are interpreting some of my works as a form of acculturation, notably those performances that incorporate traditional Indonesian dance, because they don't seem to be able to move beyond the perceived Asian (Orientalist) text/code of the dance.

In reference to Weber's model, what Ibu Sawitri says about the contemporary work I do becomes quite significant. She acknowledged that by using her dance in a different context I was creating something new in form and meaning from traditional Topeng Losari. Therefore, in honour of that new form and the original Topeng Losari, it should be called something new (for it was a kreasi baru, 'new creation'). Reinterpreting Topeng Losari in a contemporary performance context in Sydney was a necessary step in order to make it meaningful to myself and hopefully to my audience. Even though I can, and have permission to perform traditional Topeng Losari dances in Australia, and have done so on request, for me, there is more creative potential in working with the dance as a performance language, with which I can express a multitude of meanings in my own cultural context.

The issue of claiming an Asian tradition from a once colonised society is nevertheless problematic. There is no getting away from the history of colonial exploitation. As a middle-class citizen from a 'first world' nation I have access to information and have the means to travel. There is an inherent danger of being seduced into the role of the 
neo-colonizer in the search of 'hidden Eastern treasures' to make one's own. Pavis (1992) voices his suspicions of the latent colonial urge of the Westerner engaged in intercultural projects, who 'makes an effort to revitalise Western forms and traditions by adding or substituting extra-European forms. Faced with its own loss of flavour, sensuality, any link to reality at home, western culture reacts with the secular reflex of importing rejuvenating raw materials’ (cited in M. Cohen 1996, 55).

This leftover colonial sentiment is well captured by Kroll (1980) in an interview with Peter Brook:

I don't think of myself as a theatre artist. I'm not particularly interested in theatre or art as such. I'm a traveler, an explorer whom life has thrust into this field. I'm like a vulcanologist who goes from volcano to volcano, looking for the biggest eruption. I've got themes I want to explore and experiments I want to make and places I want to see. It's all part of the process I hope is getting richer and richer in human material and human discovery (cited in Dunn 1996, 32).

The sexualised language and greedy imagery here is typical of nineteenth-century colonial travel journals, photography and films produced by men. I was attempting to present visually a sense of these issues in the colonial camera box in the installation. Brook falls neatly into the category of colonial adventurer with the typical sexual fascination for volcanoes and an appetite for an abundance of sensual delights, experiences and knowledge waiting for discovery and consumption. Brook’s eclectic compilation of other cultures, perhaps those that he has gathered on his travels, and his reinterpretation of the Mahabharata, within an imperialistic framework, have been a common source of criticism of his work. Dunn elaborates:

Brook is more anthropologist than theatre director, and this is what the Orient possesses for one like him, a means for human discovery. Yet talk of the 'Orient' implies that there is an 'other' and this highlights the bias that some feel Brook has fallen victim to: in presenting the Orient Brook has placed himself back within the prevailing hierarchy, that of the Occident. For as Edward Said points out in his study, 'the Orient was not allowed to represent itself, but had to be represented by the Occident.' In other words, Brook had to re-align the stories of the Mahabharata to fit within the framework of imperialist thought. (1996, 32)

This brings me to the crucial question about my own work. Am I being the coloniser by making a traditional Indonesian dance form my language of performance expression? As I have attempted to make apparent throughout this paper, the dance skills and 
performance training I draw on in my work are the result of many years invested in learning Topeng Losari. This dance is not just a commodity that has a beginning and an end only to be transported home and put away in my big wooden chest like a treasure with all my other glitter and dancing paraphernalia. It is much more than that. It is a language through which I have gleaned an insight into another way of being in the world and that has allowed me to embody this experience and become mentally, physically and spiritually 'expanded' for it. This process has been encouraged and supported by Indonesian friends in Indonesia and Australia, starting all the way back in 1983 when my Javanese host father Mr. Soeharso, whose family I lived with for one year, invited me to dance. ${ }^{11}$ It would of course be a lie to say that I have never been dazzled and seduced by a desire to claim the beauty and sensuality of Indonesian dance forms for myself and that this desire is intrinsically linked to my own German/Australian 'transcendentally homeless' identity in transition. I would never have started if there had not been an initial attraction and fascination with the Other. However, in the course of learning this conversation shifted and is still shifting in an ongoing dialogue, which incorporates complexities from both sides of the dance floor as 'contact zone'.

In response to the 'spicy sauce' and 'loss of flavour' comments by Weber and Pavis, it needs to be established that I had no previous dance discipline to which I could add 'sauce’ or 'flavour'. Indonesian dance is my ‘first' movement language; I am illiterate in classical ballet and perform only 'broken' modern dance. I was in part addressing this issue in the installation within my camera box, by being clad from foot to waist in modern ballet clothes reminiscent of the stereotypical 'Fame! I'm gonna live forever' look, and from waist to head inside the camera box with an eclectic mix of exotic Javanese dance costumes evocative of the exotic Mata Hari. With this occidental /oriental hybrid I was trying to cut across the unspoken rule that white bodies, if they are to be seen as 'politically correct,' should only perform western dance or 'modern' adaptations of Asian dance. As an occidental performing oriental dance I am trapped in

\footnotetext{
${ }^{11}$ I have tried not to claim the traditional dances as my own, nor my contemporary performances to be traditional Indonesian dance. Any influences or representations of Indonesian dance in my performances have always been acknowledged in my program notes.
} 
the box of colonial thief and appropriator. There is very little room to move, as I demonstrated by literally trying to dance from my waist up in the confines of a 52cm by $56 \mathrm{~cm}$ by $70 \mathrm{~cm}$ rectangular box within the installation. The interspersed silent film captions in the wall projection of the installation provide a list of some of the most inane and commonly repeated questions I am asked after performances. I thought you were German. Do the hand movements mean anything? Is it hard to keep the mask on? Where did you learn to dance like that? They are the constant reminder that because my performances employ Asian dance vocabularies they cannot easily be recognised as contemporary, no matter how cutting-edge and deconstructed.

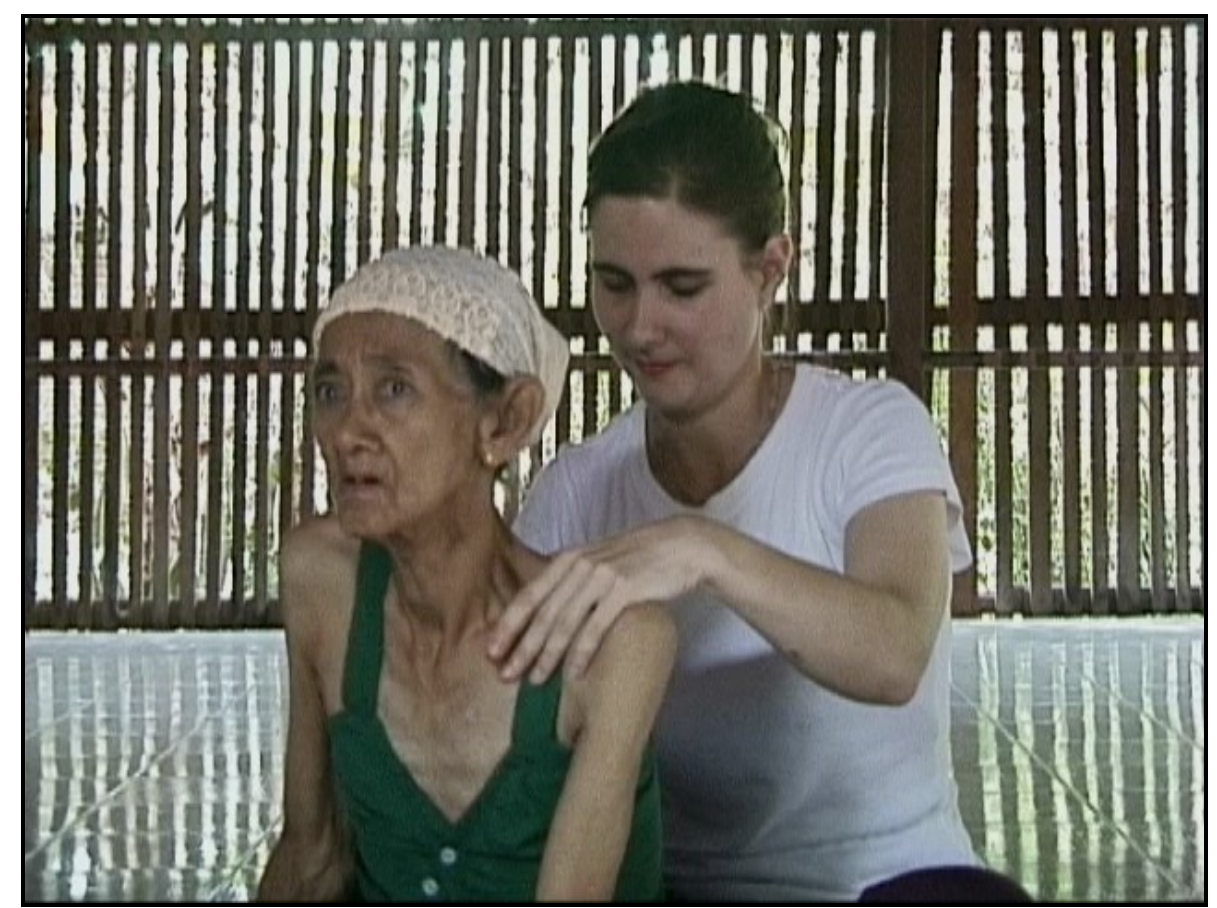

Ibu Sawitri and me in the dance studio, Losari/Cirebon 1999

This leads to the next question, do I wear an Asian mask to hide my 'whiteness,' which implicates me with historical guilt? There is no escaping historical guilt, especially considering that I come from an Australian/German background, which invariably provides me with solid doses from both sides. Perhaps on a deeper psychological level the mask did initially represent a fetish object that helped me resolve, for the duration of the dance, the two incongruous parts of West and East that make up my identity. 
McClintock provides an illuminating description of how she interprets the function of the fetish.

The fetish thus stands at the crossroads of psychoanalysis and social history, inhabiting the threshold of both personal and historical memory. The fetish marks a crisis in a social meaning as the embodiment of an impossible irresolution. The contradiction is displaced onto and embodied in the fetish object, which is thus destined to recur with compulsive repetition. Hence the apparent power of the fetish to enchant the fetishist...As composite symbolic objects, fetishes thus embody the traumatic coincidence not only of individual but also historical memories held in contradiction. $(1995,184)$

The crisis in social meaning and historical memory for me is at the heart of what I have attempted to address in Troppo Obscura, namely that I am a white body with an Asian dance vocabulary. Furthermore I am a white body inscribed with a history of violence towards the very people whose dance I am learning and creating art with. The deeper psychological meanings underpinning this seemingly impossible irresolution are about not having a firm sense of belonging to either German or Australian parent culture due to having grown up across both. This condition is coupled with having found a sense of connection and belonging to an adopted culture, Indonesia, which is communally oriented and inclusive. On a subconscious level the mask became for me the symbolic object that embodied the contradiction of the non-belonging of my skin and inscribed history, together with the sense of belonging of my body movement and heart. This contradiction and the audience response to it is visualized in Troppo Obscura's wall projection. 


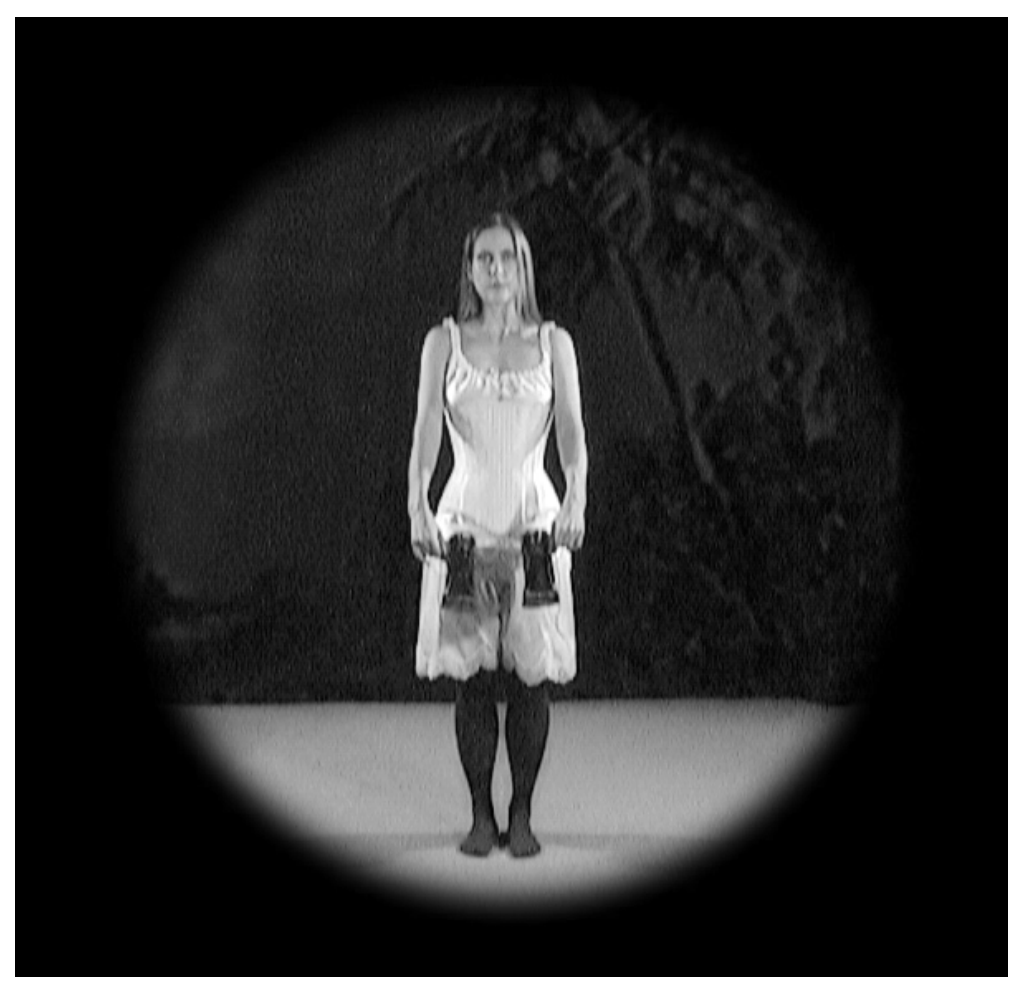

Wall-Projection, Troppo Obscura, October 2002

Directly inspired by the white-clad colonial woman from the archives who is my symbolic ancestor, I wanted to depict the image of a white body stripped naked like all the Indonesian women from the archives presented in the installation. Then, through the gradual layering of Victorian clothing that functions as a metaphor of colonial history and colonial thinking, I wanted to depict the historical build-up of a particular way of being which is western, both as perceived from within and as seen from without. Fully clad in layers of colonial history and ways of thinking, I engage in a mask dance that ends in a trick sequence of changing masks that represent the continual shift and metamorphosis of identity arising from the intersection of cultures. This is in a sense the depiction of the dance of the 'contact zone' that incorporates all the historical and individual complexities of a cross-cultural engagement. Ultimately the sequence is reversed and the clothing comes off layer by layer until I am naked again. I like to think of this as what Spivak calls the 'unlearning' or in this case the 'undressing' of Western colonial 'female privilege' $(1988,295)$. There have been times when I have felt almost paralysed by the political and historical implications of what I was doing. To stop, however, is not the answer. Chambers reminds us of the need to keep dancing the 
‘contact zone’ together.

As a third way, neither 'progressive' nor 'traditional,' the effects of this configuration are neither restricted to the 'centre' nor the 'periphery,' or 'Third World'. To hold on to the uncertainties of this mutual interrogation is imperative. Otherwise my desire continues to produce the cycles of hegemony that subject the other to my categories, to my need for alterity. Then my recognition of difference merely becomes the prison for the object of my desire. Requested to carry the burden of 'authenticity,' of 'difference,' or of 'post coloniality,' the other continues to be exploited. To be colonised, in another name (1996, 54).

The conversation needs to be kept alive in order to negotiate spaces in the 'contact zone,' that don't fall into the old top-down colonial binarism of the colonizer and colonised. Spaces need to be negotiated where all voices can be heard. Part of keeping the conversation alive involves being able to speak one another's languages. It shouldn't always be the ex-colonised speaking the ex-coloniser's language. In the process of learning the Other's language, care must be taken to not fall into the trap of speaking on behalf of the Other. Within post-colonial debate language is given special attention:

as well as encouraging translation between all languages used in the various post-colonial societies (including translations of indigenous into English and into other indigenous languages), it is equally important to insist on the metropolitan institutions and cultural practices to open themselves up to indigenous texts by encouraging the learning and use of these languages by metropolitan scholars (Ashcroft, Griffiths \& Tiffin 1998, 20).

Movement and dance is another form of language, another cultural text. By learning these other texts seriously and with respect, a new kind of conversation can be held outside the imperial framework. This is how I see the function of my work, that is, as a gesture against neo-colonialism. As intercultural performer, director and academic Richard Schechner says:

The more we, and everyone else too, can perform our own and other people's cultures the better. To perform someone else's cultures takes knowledge, a 'translation' that is different, more viscerally experiential, than translating a book. Intercultural exchange takes a teacher: someone who knows the body of performance of the culture being translated. The translator of culture is not a mere agent, as a translator of words might be, but an actual culture-bearer. This is why performing other cultures becomes so important. Not just reading them, not just visiting them but actually doing them. So that 'them' and 'us' is elided, or laid experientially side-by-side (1991, 314). 


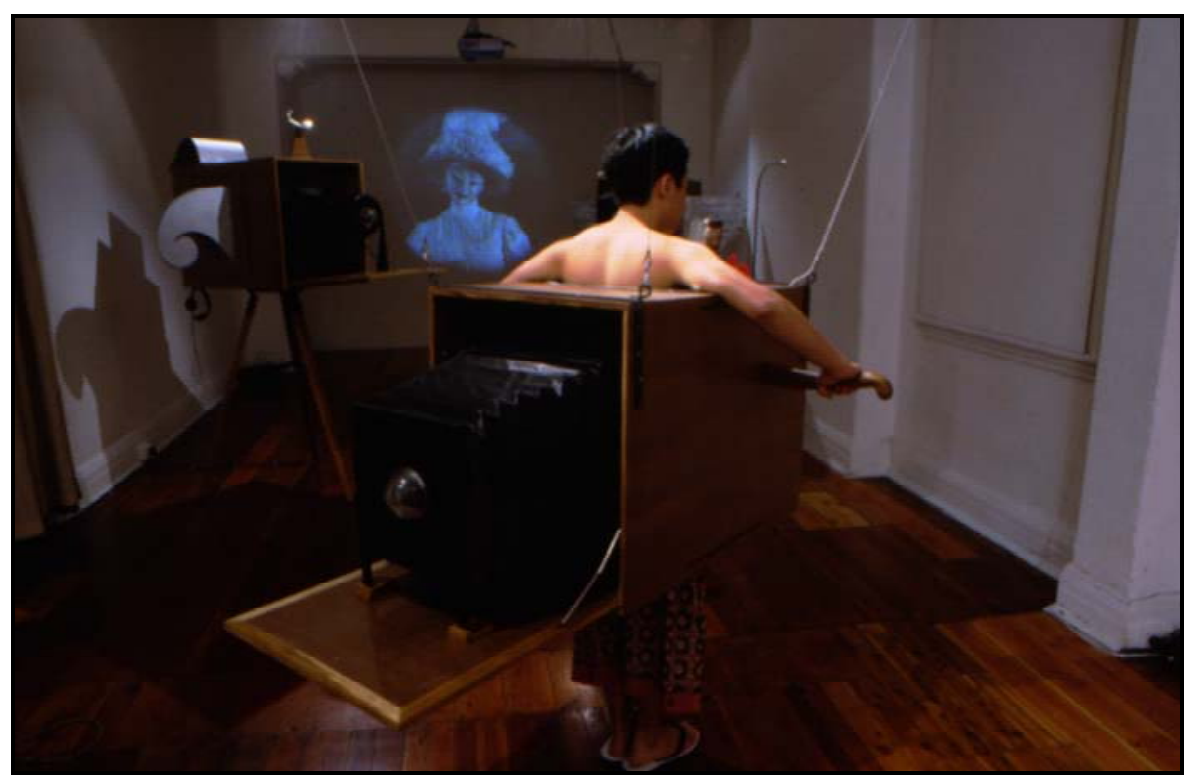

Installation space, Troppo Obscura, October 2002

In this paper and through my performance I have attempted to make visible the notion that contemporary individuals are increasingly making the shift from claiming unified, relatively homogenous identities, to acknowledging processes of identification. This can be seen as a direct result of globalisation and the information explosion. Ibu's life and dance in as small a place as Losari in Indonesia is reflective of the rapid changes taking place both domestically and globally. Throughout her life she was forced to make many adjustments on a personal level and in relation to her dance tradition. Her dance is still thriving today because she was willing to make the necessary changes and move with the times. Contrary to how many in the west would perceive it, Topeng Losari is alive and well, exercising its own fluid Indonesian form of modernity and it is not a necrotized form collecting dust behind a glass museum cabinet. Like Ibu Sawitri I have adjusted and changed as a result of the knowledge and experience gained by learning dance and living with her, as well as through the process of making Troppo Obscura informed in part by that knowledge. For many of us, inhabiting a shifting, fluid identity is a means of being able to continue existing and reinventing ourselves in a rapidly changing world. Colonial cultural 'boxing' was never appropriate and is even less relevant in today's multifaceted world. Within the current climate of global neoimperialism the unequal power distributions based on the colonial model of 'us' and 
'them' is being perpetuated. Care must be taken in the West not to perpetuate these colonial hierarchies and power imbalances within the very celebration of multicultural, post-modern notions of 'happy hybridity'(Perera 1994, 17). Through whatever means possible, whether it be discourse, ideology, or the language of dance, the time has come to (re)imagine the human subject and create new spaces where all can exist equally and find a space of representation.

\section{Reference list}

Allatson, P. 2002, Latino Dreams: Transcultural Traffic and the U.S. National Imaginary, Rodopi Press, Amsterdam and New York.

Ashcroft, B., Griffiths, G. \& Tiffin, H. 1998, Key Concepts in Post-Colonial Studies, Routledge, London; New York.

Chambers, I. 1996, 'Signs of Silence, Lines of Listening,' in I. Chambers \& L. Curti (eds), The Post-Colonial Question: Common Skies, Divided Horizons, Routledge, London, New York, 47-65.

Chin, D. 1991, 'Interculturalism, Postmodernism, Pluralism,' in B. Marranca \& G. Dasgupta (eds), Interculturalism and Performance, PAJ Publications, New York.

Cohen, M. 1996, 'Seventeen Stories about Interculturalism and Tadashi Suzuki,' About Performance, Centre for Performance Studies University of Sydney, vol. 2, 5159.

Dunn, S. 1996, 'Cross Cultural Productions: Peter Brook and the Mahabaratha,' About Performance, Centre for Performance Studies University of Sydney, vol. 2, 2741.

Echols, J. \& Shadily, H. 1992, An Indonesian-English Dictionary, PT Gramedia, Jakarta.

Hage, G. 2003, 'The Anatomy of Anti-Arab Racism,' The Australian Financial Review, 15 August, p. 9.

Lucas, A. 1997, 'Images of Javanese Women During the Japanese Occupation 194245,' in J. Gelman Taylor (ed.), Women Creating Indonesia: The First Fifty

Years, Monash Asia Institute, Melbourne, pp. 52-91.

Masunah, J. 2000, Sawitri Penari Topeng Losari, Tarawang, Yogyakarta.

McClintock, A.J. 1995, Imperial Leather, Routledge, New York, London.

Pratt, M.L. 1992, Imperial Eyes: Travel Writing and Transculturation, Routledge, London and New York.

Said, E. 1996, 'From Orientalism,’ in P. Mongia (ed.), Contemporary Post Colonial Theory, Arnold, New York.

Sawitri 1996, Interview with the author, Losari/Cirebon (Indonesia).

Sawitri 1999, Interview with the author, Losari/Cirebon (Indonesia).

Schechner, R. 1991, 'Intercultural Themes,' in B. Marranca \& G. Dasgupta (eds), Interculturalism and Performance, PAJ Publications, New York. 
Spivak, G. 1988, 'Can the Subaltern Speak?’ in G. Nelson \& L. Grossberg (eds), Marxism and the Interpretation of Culture, MacMillan, London, 271-313.

Suzuki, T. 1991, 'Culture is the Body,' in B. Marranca \& G. Dasgupta (eds), Interculturalism and Performance, PAJ Publications, New York.

Thompson Zainu'ddin, A. 1997, 'Building the Future: The Life and Work of Kurnianingrat Ali Sastroamijoyo,’ in J. Gelman Taylor (ed.), Women Creating Indonesia: The First Fifty Years, Monash Asia Institute, Melbourne, 156-203.

Tiwon, S. 1996, 'Models and Maniacs,' in L.J. Sears (ed.), Fantasizing the Feminine in Indonesia, Duke University Press, Durham \& London, pp. 47-71.

Torgovnick, M. 1991, Gone Primitive: Savage Intellects, Modern Lives, University of Chicago Press, Chicago.

Weber, C. 1991, ‘AC/TC: Currents of Theoretical Exchange,’ in B. Marranca \& G. Dasgupta (eds), Interculturalism and Performance, PAJ Publications, New York. 